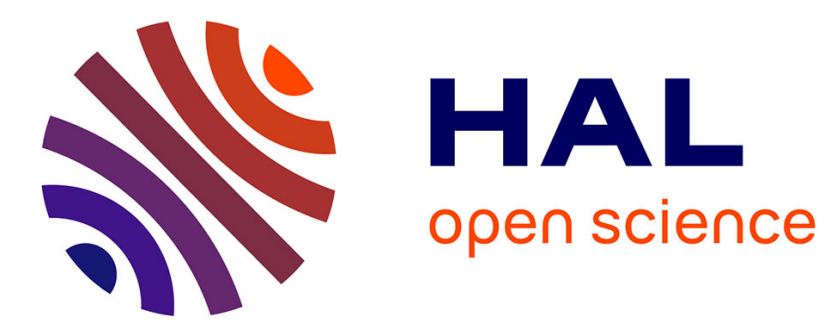

\title{
Dietary exposure to acrylamide from potato crisps to Spanish population
}

\author{
Gema Arribas-Lorenzo, Francisco J. Morales
}

\section{To cite this version:}

Gema Arribas-Lorenzo, Francisco J. Morales. Dietary exposure to acrylamide from potato crisps to Spanish population. Food Additives and Contaminants, 2009, 26 (03), pp.289-297. 10.1080/02652030802477954 . hal-00577341

\section{HAL Id: hal-00577341 \\ https://hal.science/hal-00577341}

Submitted on 17 Mar 2011

HAL is a multi-disciplinary open access archive for the deposit and dissemination of scientific research documents, whether they are published or not. The documents may come from teaching and research institutions in France or abroad, or from public or private research centers.
L'archive ouverte pluridisciplinaire HAL, est destinée au dépôt et à la diffusion de documents scientifiques de niveau recherche, publiés ou non, émanant des établissements d'enseignement et de recherche français ou étrangers, des laboratoires publics ou privés. 


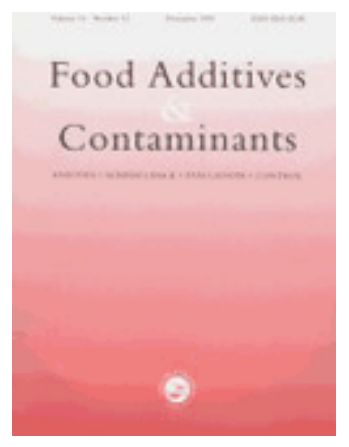

\section{Dietary exposure to acrylamide from potato crisps to Spanish population}

\begin{tabular}{|c|c|}
\hline Journal: & Food Additives and Contaminants \\
\hline Manuscript ID: & TFAC-2008-190.R1 \\
\hline Manuscript Type: & Original Research Paper \\
\hline $\begin{array}{r}\text { Date Submitted by the } \\
\text { Author: }\end{array}$ & 11-Sep-2008 \\
\hline Complete List of Authors: & $\begin{array}{l}\text { Arribas-Lorenzo, Gema; Consejo Superior de Investigaciones } \\
\text { Cientificas, Instituto del Frio } \\
\text { Morales, Francisco J.; Consejo Superior de Investigaciones } \\
\text { Cientificas, Instituto del Frio }\end{array}$ \\
\hline Methods/Techniques: & Chromatography - LC/MS, Exposure, Survey \\
\hline Additives/Contaminants: & Acrylamide \\
\hline Food Types: & Potatoes, Processed foods \\
\hline
\end{tabular}

\section{SCHOLARONE Manuscripts}




\section{Dietary exposure to acrylamide from potato crisps to Spanish}

2 population

3

4 G. ARRIBAS-LORENZO and F.J. MORALES*

5

6 Consejo Superior de Investigaciones Científicas,

7 Instituto del Frío, 28040, Madrid, Spain.

$15{ }^{*}$ Corresponding author:

16 Francisco J. Morales, Instituto del Frío, CSIC.

17 José Antonio Novais 10, 28040, Madrid, Spain.

18 Telephone: +34 915492300

19 Fax: +34 915493627

20 E-mail: fjmorales@if.csic.es 


\section{Abstract}

2 Potato crisps are one of the food commodities which contributes most to overall dietary

3 human exposure of acrylamide. This investigation has estimated the dietary exposure to

4 acrylamide form potato crisps in the Spanish population. Sampling of potato crisps (n

$5=36$ ) from 16 different producers were carried put in March 2008. An average level of

$6740 \mu \mathrm{g} / \mathrm{kg}$ (ranging from 81 to $2622 \mu \mathrm{g} / \mathrm{kg}$; min:max) and a median of $592 \mu \mathrm{g} / \mathrm{kg}$ were

7 obtained. Acrylamide levels in marketed potato crisps have been significantly reduced

8 (nearly to 50\%) compared with a previous sampling performed 4 years earlier. The

9 observed signal value $\left(90^{\text {th }}\right.$ percentile) was $1377 \mu \mathrm{g} / \mathrm{kg}$ with $86 \%$ of the samples with

10 acrylamide levels lower than $1000 \mu \mathrm{g} / \mathrm{kg}$. Dietary exposure to acrylamide from potato

11 crisp consumption in total Spanish population was estimated to be $0.042 \mu \mathrm{g} / \mathrm{kg} \mathrm{bw} / \mathrm{day}$

12 by using a deterministic approach based on National consumption database. In a second

13 study, dietary exposure (based on 3-day food record) was determined to be $0.053 \mu \mathrm{g} / \mathrm{kg}$

$14 \mathrm{bw} /$ day for the adult population (17-60 years) and $0.142 \mu \mathrm{g} / \mathrm{kg}$ bw/day for children (7-

1512 years). The contribution of potato crisps to the estimated dietary acrylamide

16 exposure of the Spanish population is moderate as compared with other European

17 member states.

18

19

20 Keywords: acrylamide, dietary intake, potato crisps, food contaminant 


\section{Introduction}

3 (Tareke et al. 2002), a large number of studies have been published and summarized in

4 reviews (Friedman 2003; Wenzl et al. 2003; Taeymans et al. 2004; Zhang et al. 2005)

5 where basically acrylamide levels can be seen to depend on the raw materials, additives

6 and processing parameters. Acrylamide is clearly genotoxic and carcinogenic in studies

7 in animals, and causes increased tumor incidence at a variety of sites (IARC 1994; EC

8 2000). The International Agency on Research on Cancer has classified ACRYLAMIDE

9 as "probably carcinogenic to humans (IARC Group 2A)". The MOE (Margin of

10 Exposure) is calculated by dividing the toxicity estimate from animal experiments by

11 the estimated intake from food. Consequently, the lower the MOE the greater is the

12 public health concern. The MOEs were thus calculated to be 300 for the general

13 population and just 75 for high consumers, including children; being concluded that

14 acrylamide in food is a potential public health hazard (FAO/WHO 2005). The Scientific

15 Committee of EFSA (EFSA 2005) also endorsing a MOE approach for compounds that

16 are both carcinogenic and genotoxic is of the view that a MOE of 10,000 or larger

17 would be of low concern from a public health point of view and might be considered as

18 a low priority for risk management actions (HEATOX project, final report, April 2007).

19 Toxic effects have been evaluated by IARC (1994), WHO/JECFA (2005), reported in

20 special issues (i.e. Mutation Research 2005), and its nutritional risk evaluated

21 (Alexander 2006). A comprehensive review of acrylamide toxicity including

22 mechanisms and risk assessment has recently appeared (Shipp et al. 2006; Parzelfall

23 2008). Last EFSA experts meeting (22-23, May, Tabiano, Italy) on acrylamide agreed

24 to maintain the level of concern and to revise the situation in 2009 with new

25 epidemiological data. 
1 Potato products, such as crisps and French fries, are among the major

2 contributors to the acrylamide daily intake, especially for children and teens (Wilson et

3 al. 2006). Many studies have been accomplished to find strategies to minimize the

4 levels of acrylamide, such as controlling levels of reducing sugars in fresh tubers

5 (Amreim et al. 2004; Matthäus et al. 2004), agronomical factors (Noti et al. 2003) apply

6 appropriate storage conditions (De Wilde et al. 2005), modifying soaking or blanking

7 (Pedreschi et al. 2004), reducing frying temperature and time (Gertz and Klostermann

8 2002; Kita et al. 2004; Franke et al. 2005), addition of additives (Mestdash et al. 2008)

9 or cations (Gökmen and Senyuva, 2007). Alternatives to traditional frying such as

10 vacuum frying (Granda et al., 2004) or combined pre-treatment by microwave heating

11 (Edoggu et la., 2007) or prefrying (Pedreschi et al., 2007) have been proposed. The

12 subject has been recently reviewed by Morales et al. (2008).

13 JECFA estimated that the major contributing foods to total human exposure to

14 acrylamide for most countries are potato chips (French fries, 16-30\%), potato crisps

15 (chips, 6-46\%), coffee (13-39\%), pastry and sweet biscuits (cookies, 10-20\%), bread,

16 rolls and toast $(10-30 \%)$ and others $(<10 \%)$. JECFA concluded that based on national

17 estimates, an intake of acrylamide of $1 \mu \mathrm{g} / \mathrm{kg}$ bw/day could be taken to be representative

18 as average for the general population and that an intake of $4 \mu \mathrm{g} / \mathrm{kg}$ bw/day could be

19 taken to represent consumers with a high intake, including children. Estimating

20 consumer exposure to acrylamide is a high priority for governments and industry alike

21 where new exposure models have been recently developed that provide estimates of

22 exposure of typical consumers and extreme consumers as well (Dybing et al. 2005).

In 2007, the European Commission made recommendations to monitor levels of

24 acrylamide in certain food categories (2007/331/EC), these data will be compiled by

25 members states and reported to EFSA on a yearly basis for the next three years (EC 
1 2007). Activities have not been equal across EU since overall dietary exposure has only

2 been estimated for a certain numbers of member states. In Spain, like many other

3 Mediterranean countries, estimation has not been undertaken yet. It might be anticipated

4 that there will be considerable differences between EU countries due to differences in

5 food consumption habits, including traditional foods.

6 Given the popularity of potato crisps, particularly among younger age groups, it

7 is important to assess the daily intake of acrylamide from crisps in the Spanish diet. In

8 parallel it is also relevant to obtain a picture of the current situation and monitoring

9 progress in minimisation strategies applied at industrial level and to compare the intake

10 with other EU state members before to further decision on risk management. This

11 investigation present a survey on commercial potato crisps in Spain and its contribution

12 to daily intake of acrylamide based on two exposure models, as a comprehensive step to

13 afford a precise study in a future by Spanish Administration bodies. 
1 Materials and methods

2 Chemicals.

3 All chemical used were of an analytical grade and were obtained from Sigma-

4 Aldrich (St. Louis, MO, USA), unless mentioned otherwise. ${ }^{13} \mathrm{C}_{3}$-Acrylamide (isotopic

5 purity 99\%) was from Cambridge Isotope Labs (Andover, MA, USA). Oasis-HLB

6 cartridges (30 mg, $1 \mathrm{~mL}$ ) were from Waters (Milford, MA, USA).

7

$8 \quad$ Samples

9 Experiments were conducted with a series of commercial potato chips (36

10 brands from 16 producers) randomly purchased on different supermarkets between $10^{\text {th }}$

11 to $18^{\text {th }}$ March 2008. In this period, stored potatoes were likely used by producers.

12 Samples from the same brand containing different flavorings and/or spices added were

13 not included in the sampling since frying variables and raw material should be similar.

14 Samples (200 - 500 g) were mixed and thinly sliced to assure a homogeneous

15 distribution of potential hot-spots. A portion (200 g) was distributed in four containers

16 and stored under vacuum and light protected at $4^{\circ} \mathrm{C}$ until analysis.

18 LC-ESI-MS determination of acrylamide.

19 Sample preparation as described by Şenyuva and Gökmen (2006) was used with minor

20 modifications. A finely ground sample $(0.450 \mathrm{~g})$ was then weighed into a $10 \mathrm{~mL}$

21 centrifuge tube. The sample was spiked with $100 \mu \mathrm{L}{ }^{13} \mathrm{C}_{3}$-labelled acrylamide (10

$22 \mu \mathrm{g} / \mathrm{mL}$ ) for recovery, and $5 \mathrm{~mL}$ of Milli-Q water was added. Then the mixture was

23 vortexed, kept for five minutes at room temperature and subsequently homogenized for

$241 \mathrm{~min}$ (Ultraturrax). Then, $750 \mu \mathrm{L}$ Carrez I and $750 \mu \mathrm{L}$ Carrez II solution were added,

25 vortexed and left to stand for 10 minutes. Tubes were centrifuged at $5000 \mathrm{rpm}$ for 15 
1 minutes at $4{ }^{\circ} \mathrm{C}$. The clear supernatant $(1 \mathrm{~mL})$ was clarified onto a pre-conditioned HLB

2 cartridge. The first drops were discharged and the rest of the eluate was collected in

3 amberlite vials for analysis.

4

5 LC-ESI-MS analyses were performed as described by Rufian-Henares et al. (2007) with

6 minor modifications (Morales and Arribas-Lorenzo 2008) using an Agilent 1100 HPLC

7 system (Waldbronn, Germany) consisting of a quaternary pump, an autosampler and a

8 temperature-controlled column oven, coupled to an Agilent 1100 MS detector equipped

9 with an electrospray ionization interface. The analytical separation was performed on an

10 Inertsil ODS-3 column $(250 \times 4.6 \mathrm{~mm}, 5 \mu \mathrm{m})$ using an isocratic mixture of $0.2 \%$

11 aqueous solution of formic acid at a flow rate of $0.6 \mathrm{~mL} / \mathrm{min}$ at $25^{\circ} \mathrm{C}$. Data acquisition

12 was performed, with a delay time of $8 \mathrm{~min}$, in a selected ion monitoring (SIM) mode

13 using the following interface parameters: a drying gas $\left(\mathrm{N}_{2}, 100 \mathrm{psig}\right)$ flow of $12 \mathrm{~L} / \mathrm{min}$,

14 nebulizer pressure of $45 \mathrm{psig}$, drying gas temperatures $350^{\circ} \mathrm{C}$, a capillary voltage of 3

$15 \mathrm{kV}$ and a fragmenter voltage of $70 \mathrm{eV}$. Monitored ions were $72.1 \mathrm{~m} / \mathrm{z}$ for acrylamide

16 and $75.1 \mathrm{~m} / \mathrm{z}$ for ${ }^{13} \mathrm{C}_{3}$-labeled acrylamide. An acrylamide calibration curve was built in

17 the range of 2-100 $\mu \mathrm{g} / \mathrm{L}$ and a limit of quantification was determined to be $25 \mu \mathrm{g} / \mathrm{kg}$ for

18 potato crisps. The method was in-house validated for linearity, precision and recovery.

19 Furthermore, the accuracy was recently demonstrated for potato crisps in an

20 interlaboratory comparison study launched by IRMM, yielding a z-score of -0.5 .

21 Precision (reproducibility) was lower than 12\% and recovery between $84-109 \%$. The

22 analyses are integrated within the scope of a certified laboratory controlled by AENOR

23 (Spanish Association for Standardisation and Certification).

25 Food consumption data. 
1 In order to calculate the dietary intake of acrylamide from potato crisps two different

2 food consumption data were used. A first exposure study was carried out from the

3 Spanish National Agricultural, Fishing and Food Administration based on a yearly

4 consumption database. It is a food survey annually published (MAPA 2007). This is the

5 most recent measurement of dietary consumption in Spain at a national level. In this

6 survey data are collected from 8240 interviews to non-institutionalized households and

7898 interviews to restaurants, catering services, Institution (hospital, public schools,

8 penitentiary, etc), covering 2006. The statistical universe of the study compile a

9 balanced, representative and stratified probability sample of the Spanish population

10 taking into account, gender, ages, regions, socio-economic status, among others. An

11 average body weight of $70 \mathrm{~kg}$ was used to estimate the total daily intake of acrylamide

12 to total population and expressed as $\mu \mathrm{g} / \mathrm{kg}$ bw/day. A second exposure study was

13 calculated from food consumption data survey from the National Food Safety and

14 Nutrition Agency in Spain (AESA 2006). This study was elaborated in 2003 with Food

15 Frequency Questionnaires over 1963 subjects from $0-60$ years grouped in six levels of

16 age ( $>1$ year, 1-2 years, 2-7 years, 7-12 years, 12-17 years, and $>17$ years) in three

17 consecutive days.

19 Statistical Analysis.

20 Analyses were performed using Statgraphics Plus, version 5.1, 2001 (Statistical

21 Graphics Corp, Rockville, MD, USA). At least, two independent analyses were carried 22 out per sample. 


\section{$1 \quad$ Results and Discussion}

2 Thirty-six classical potato chips from 16 different producers, without flavor or species

3 added were analyzed for acrylamide content. Acrylamide content ranged from 81 to

$42622 \mu \mathrm{g} / \mathrm{kg}$ with a mean value of $740 \mu \mathrm{g} / \mathrm{kg}$ and a median of $592 \mu \mathrm{g} / \mathrm{kg}$. Similar values

5 were reported by other authors (Becalski et al. 2003; Roach et al. 2003; Rosen and

6 Hellenas 2002; Tareke et al. 2002; Matthys et al. 2005) who found acrylamide levels

7 ranged between 224 and $3700 \mu \mathrm{g} / \mathrm{kg}$. Recently a survey on acrylamide levels in potato

8 crips in the Turkish market showed a median level of $818 \mu \mathrm{g} / \mathrm{kg}(59-2336$, min-max $)$

9 (Ölmez et al., 2008). Institute of Reference of Measurements and Materials developed a

10 monitoring database which was last updated in June 2006 (IRMM 2006; Wenzl and

11 Anklan, 2007). A median level of $528 \mu \mathrm{g} / \mathrm{kg}(5-4215 \mu \mathrm{g} / \mathrm{kg}$; $\min -\max , \mathrm{n}=836)$ is

12 reported which is in line with values obtained in current survey. Results are also in

13 concordance with the monitoring database (2002-2004) from FDA with a mean of 612

$14 \mu \mathrm{g} / \mathrm{kg}$ and a median of $462 \mu \mathrm{g} / \mathrm{kg}$ (www.cfsan.fda.gov). Figure 1 depicted the

15 acrylamide distribution in the survey. All samples analysed contains ACRYLAMIDE

16 levels higher the LOQ.

17 However, levels of acrylamide in potato crisp marketed in Spain has been

18 significantly reduced as compared with a previous sampling dated on 2004 (Rufian-

19 Henares and Morales 2005). In the 2004 sampling, a median and mean of 1180 and

$201484 \mu \mathrm{g} / \mathrm{kg}$ was obtained where nearly a $50 \%$ reduction is reached in the current study.

21 In addition, values for the first quartile and third quartile are diminished as well, and

22 subsequently minimizing the heterogeneity of the distribution (Figure 2).

Acrylamide reduction was analytically confirmed in the potato crisps marketed

24 in Spain as compared with 4 years ago. Toolbox from the CIAA compile a number of

25 recommendations for effective acrylamide mitigation at industrial scale which seems to 
1 be effective among Spanish potato crisps producers (CIAA 2007). But, implementation

2 of the Toolbox guidelines to SMEs is a challenge where accessibility to information is

3 mediated by local federations of producers. Guidelines are focussed on agronomical

4 factors, storage conditions, pre-treatment and processing conditions. At this level, it

5 cannot be stated if acrylamide reduction in the Spanish potato crisps market has been

6 due to implementation of one guideline or it is a sum of all of them. Selection of an

7 adequate potato tuber variety with reducing sugars content lower that $0.3 \%$ is

8 appropriate for potato crisps (CIAA, 2007). It is also noteworthy to mention that

9 Spanish Food Safety and Nutrition Agency (AESAN) has implemented a global strategy

10 to reduction the consumption of fat, called NAOS. According to the package label as

11 declared by companies, 6 samples (aprox. 17\% from total) contained levels of fat lower

12 than $25 \%$ and claiming for light potato crisp in the container. Indeed, fat content was the

13 variable with higher dispersion among the samples, if compared with protein and

14 carbohydrate content. Therefore it was found any significant correlation between fat

15 content and levels of acrylamide. Samples with low fat content are depicted in figure $\mathbf{1}$

16 as well.

18 WHO/JEFCA and the Scientific Panel on Contaminants in the Food Chain (CONTAM)

19 of the European Union aimed to investigate strategies to reduce acrylamide formation

20 by implementing the ALARA principle (as low as reasonably or technically

21 achievable). The German Federal Office of Consumer Protection and Food Safety

22 (BVL) stated a signal value $1000 \mu \mathrm{g} / \mathrm{kg}$ for potato crisps, as a concept of minimization

23 (BVL 2006). The signal value is defined as the lowest level of the $10 \%$ containing the

24 highest level of acrylamide in a food commodity. If acrylamide contents were above

25 this signal value, food producers should be recommended to take adequate actions to 
1 lower such contents, but at present there is not regulations or obligation in the European

2 countries. Since 2002, BVL published yearly the observed value for potato crisps being

$31500,1200,1470,1029$, and $1333 \mu \mathrm{g} / \mathrm{kg}$ for the years 2002, 2003a, 2003b, 2004 and

42005 respectively. If the German minimisation concept is applied to the Spanish potato

5 crisps survey, most of the samples $(86 \%)$ contained acrylamide levels lower than 1000

$6 \mu \mathrm{g} / \mathrm{kg}$. However the observed value was calculated to $1377 \mu \mathrm{g} / \mathrm{kg}$ being about $61 \%$

7 lower than value recorded in the 2004-sampling.

8

9 For monitoring the progress in the minimisation strategies by industrials, it is useful to

10 define limits for quality control. Three levels can be identify, acceptable (below $50^{\text {th }}$

11 percentile), under evaluation $\left(50^{\text {th }}-90^{\text {th }}\right.$ percentile) and unacceptable $\left(>90^{\text {th }}\right.$

12 percentile), as displayed in Figure 1. Samples lying in the upper region should

13 reconsider the internal quality strategy, for instance, increasing quality controls to fresh

14 potato suppliers. Many studies demonstrated that it is possible to define time-

15 temperature processing conditions which guarantee low acrylamide concentration and

16 the retention of sensorial properties in terms of colour, flavour, and starch gelatinization

17 (i.e. Pedreschi et al. 2006). It is necessary an adjustment of the traditional frying

18 conditions, supervision of the process, and improve traceability of fresh potatoes during

19 storage period by potato suppliers. Monitoring database of the IRMM which tend to

20 resemble the situation across Europe members states, recorded at the $90^{\text {th }}$ percentile of

$211442 \mu \mathrm{g} / \mathrm{kg}$ (Wenzl and Anklan, 2007), which is also in line with reported for the

22 Spanish market.

Dietary intake of acrylamide from potato crisp 
1 Spanish authorities (Spanish National Agency of Food Safety and Nutrition, AESAN,

2 http://www.aesan.msc.es/) have not reported yet mean intake values for acrylamide for

3 the Spanish population and the most contributing food categories are lacking as well.

4 This investigation is a starting point to characterise the exposure to potato crisp which is

5 one of the most contributing food categories to acrylamide intake. In general, target

6 food categories can be groped in three classes according to moderate consumption but

7 high concentration of acrylamide (a), foods with high consumption but relatively low

8 levels of acrylamide (b), and tailored-foods to specific population groups such as elders

9 or infants. Potato crisps have been identified as a major source of exposure by several

10 previous studies (Svensson et al. 2003; Matthys et al. 2005; Boon et al. 2005). But

11 contribution of regional and local foods should be explored, like fried-dough pastries

12 (Morales and Arribas-Lorenzo 2008). Although the levels of acrylamide in some of

13 these products are low, they can contribute significantly to the overall intake of

14 acrylamide. The intake of acrylamide depends consequently on the consumption pattern

15 and the acrylamide levels in foods. Contribution of individual foods to total exposure

16 can be best identified by the deterministic approach (Petersen and Tran 2005). Two

17 different consumption databases have been used for estimation of the dietary acrylamide

18 exposure from potato crisp.

20 First exposure assessment was estimated from the National consumption database 21 monitored during 2006 (MAPA 2007). Although the point estimate (deterministic 22 approach) does not assess the probability or uncertainties or even do not identify high 23 risk consumers since is based on population and not in subjects, it is a first 24 approximation and a useful screening tool in order to design a more specific study in 25 case of a potential risk. Indeed, many of the earlier data reported in literature have been 
1 obtained from generalist food intake studies for nutritional or economical monitoring

2 purposes but they were not specifically designed for food safety issues (Dybing et al.

3 2005). Furthermore, other studies link national consumption patterns with general

4 acrylamide databases (Boon et al. 2005). In summary, to date a comprehensive study

5 specifically designed for assessing the dietary acrylamide exposure is missing due to its

6 complexity.

8 During 2006, $16 \%$ of the fresh potatoes consumed in Spain were processed, and mostly

9 bought directly by consumers $(84 \%)$ as compared with consumption at restaurants,

10 catering services or Institutions (hospitals, penitentiary, schools, etc.). It represents an

11 overall estimation of consumption of $1,44 \mathrm{~kg}$ processed potato products per capita. In

12 this estimation, it has not been included the frozen potato products with are mainly par-

13 fried French fries. Average contribution of potato crisps to dietary acrylamide exposure

14 in Spain (assuming a body weight of $70 \mathrm{~kg}$ ) is calculated to $0.042 \mu \mathrm{g}$ acrylamide $/ \mathrm{kg}$

15 bw/day. One limitation of the calculation is that one single level of consumption is used,

16 but it has been compared with the distribution of acrylamide calculated in the 17 commercial sampling. The risk scenario $\left(95^{\text {th }}\right.$ percentile) is obtained with a level of $180.117 \mu \mathrm{g}$ acrylamide/kg bw/day but this level does not identify subjects with high 19 consumption patterns. Selecting high residue levels $\left(95^{\text {th }}\right.$ percentile $)$ in potato crisps will 20 very likely to overestimate the exposure. More realistic estimates of low and high 21 exposure are obtained by using probabilistic models (i.e. Monte Carlo modelling) that 22 include residues and distribution consumption patterns. As formerly explained, the 23 deterministic method applied in this study is a useful tool for estimating mean exposure 24 of population to acrylamide. 
1 The sources of acrylamide in foods vary with national or even local dietary habits. The

2 contribution of potato products is high but can vary among countries. Table I describes

3 the estimation of total dietary exposure to acrylamide and contribution calculated for

4 potato crisps as reported in different studies. For some other studies, sum of French

5 fries, potato crisps, and roasted potatoes is reported. Potato crisps, French fries and

6 other products are consumed at relatively high amounts in the US (35\% of the daily

7 intake of acrylamide) (FDA 2004), but it is even higher in The Netherlands with French

8 fries and crisps taken together contributing up to 50\% (Konings et al. 2003; Boon et al.

9 2005). In general, JECFA has estimated the variability in the potato crisps contribution

10 between 6 to $46 \%$ of the dietary acrylamide exposure, although recently Arisseto et al.

11 (2007) reported a contribution up to $60 \%$ of potato products in the Brazilian population.

12 Dietary acrylamide exposure of Spanish consumers has been significantly reduced as

13 compared with previous study (Morales 2004, unpublished). It is nearly 3.5-fold lower

14 than in The Netherlands (Konings et al. 2003) but in line with Sweden (Svensson et al.

15 2003). According to the most recent data, average human intake is estimated to be 0.4

$16 \mu \mathrm{g} / \mathrm{kg}$ bw/day from two years of age onwards. However, intake may vary widely from

170.3 to $2 \mu \mathrm{g} / \mathrm{kg}$ bw/day or may reach even $5 \mu \mathrm{g} / \mathrm{kg}$ bw/day at the 99 th percentile 18 (WHO/JECFA 2005).

20 In consumer exposure assessments it is also important to know whether there are 21 significant differences among different subgroups of the population. National 22 consumption database identify 5 classes for indexing according to regions (17 levels for

23 different Autonomous Communities), size of cities (5 levels), socioeconomic status (4 24 levels), family members (5 levels) and cycle of life (8 levels). It was observed that there 25 are great differences depending on the different categories studied, almost doubling the 
1 estimated exposure (Table II). In a simplistic overview, it can be observed that highest

2 risk of exposure is recorded for young singles of high+medium-high socioeconomic

3 status living at large cities in Catalonia. At the opposite, lowest exposure is expected for

4 large families with kids with low socioeconomic status living in villages $(<2000$

5 inhabitants) at the Canaries Islands.

6

7 The second study for exposure estimation was applied on the basis of a consumption

8 study performed on food frequency questionnaires in three consecutive days to different

9 population groups (AESA 2006). In this study it is recorded two levels of consumers

10 apart to obtain the average daily level of potato crisps intake. Regular consumers are

11 identified as subjects with some consumption of the product and represent the $33.11 \%$

12 of the children population and $21.32 \%$ of the adult population. It is also identified the

13 acute consumption at $97.5^{\text {th }}$ percentile. Table III summarised the results. Average

14 dietary exposure to acrylamide for children is 2.6 fold the exposure for adults. This is

15 expected due to a combination of lower body weight and higher caloric demand giving

16 a higher net consumption. But also by a different dietary pattern, with higher

17 consumption of certain foodstuffs rich in acrylamide, such as French fries and potato

18 crisps (Dybing et al. 2005; Wilson et al. 2006). It is thus clear that certain subgroups

19 demonstrate especially high exposure to acrylamide. This ratio is in line with compiled

20 by earlier studies (WHO 2005; EFSA 2005). In the worst scenario the highest intake

21 will be 1.064 and $0.602 \mu \mathrm{g} / \mathrm{kg} \cdot \mathrm{bw} /$ day for children and adults. In 2004, our group

22 estimated the contribution of potato crisps to total dietary intake to be $22 \%$ (Morales,

232004 unpublished). In the assumption that the pattern will be maintained, a risk intake

$24\left(97.5^{\text {th }}\right.$ percentile) of $3.01 \mu \mathrm{g} / \mathrm{kg} \cdot \mathrm{bw} /$ day is expected which is lower than $4 \mu \mathrm{g} / \mathrm{kg}$

25 bw/day, calculated by WHO (WHO 2005). 
1 Average levels of acrylamide exposure determined by food consumption database (adult

2 population, $0.053 \mu \mathrm{g} / \mathrm{kg}$ bw/day) and 3-day food records (total population, $0.042 \mu \mathrm{g} / \mathrm{kg}$

3 bw/day) studies are rather similar, and both values are low when compared with other

4 countries (table I). Again, it is noteworthy to mention that expected exposure of

5 Spanish population to acrylamide from potato crisps is moderate. But, industrials should

6 keep the inspections and controlling the process chain to reduce, if still technically

7 possible, the levels in the acrylamide in the final product to achieve the lowest

8 contribution of potato crisps to global exposure to acrylamide on the Spanish

9 population. However, pattern of consumption are rather different among the Spanish

10 regions and some effort should be addressed by local administrations to reduce potato

11 crisp consumption in regions with acute exposure levels although globally the exposure

12 is moderate as compared with other countries. It is mandatory in near future to design a

13 specific consumers study for acrylamide. In the study, foods which are known to be

14 potential sources for acrylamide should be clearly identified. On the other hand, there is

15 a need to maintain a balance between health-promoting and nutritional components of

16 the foods with minimisation strategies to reduce acrylamide exposure, apart to sensorial

17 properties accepted by consumers. Before any proposal of risk management or

18 intervention by regulatory bodies, a critical evaluation of the situation is necessary.

\section{Acknowledgements}

21 We are grateful to thank S. Martín, S. de la Peña, D. Gomez, M.A. Martinez-Bartolome

22 for technical assistance. Consejería de Educación y Ciencia (Comunidad Autónoma de

23 Madrid) is thanked for supporting a predoctoral grant for G. Arribas-Lorenzo. This

24 research was partly supported by a Scientific Reseach Programme of the Comunidad de

25 Madrid (ANALISYC, S-505/AGR-0312) and a European Collective Research Project 
1 (CT-2005-516415) supported by the Sixth Framework Programme for Research and

2 Technological Development. 
1 References

2

3 AESA. 2006. Modelo de dieta española para la determinación de la exposición del

4 consumidor a sustancias químicas. Ed. Ministerio de Sanidad y Consumo, Agencia

$5 \quad$ Española de Seguridad Alimentaria.

6 AFSSA. 2005. French Food Safety Agency. Report on Acrylamide exposure.

7 http://www.afssa.fr/Documents/RCCP2002sa0300b.pdf

8 Alexander J. 2006. Risk assessment techniques for acrylamide. In: Skog, K., Alexander,

9 J. (Eds.), Acrylamide and other hazardous compounds in heat-treated foods. CRC

$10 \quad$ Press, Boca Raton, pp. 275-295.

11 Amrein TM, Schonbachler B, Rohner F, Lukac H, Schneider H, Keiser A, Escher F,

12 Amadò R. 2004. Potential for acrylamide formation in potatoes: Data from the 2003

13 harvest. European Food Research and Technology, 219, 572-578.

14 Arisseto A, Toledo MC, Govaert Y, van Loco J, Fraselle S, Caroba D. 2007.

15 Toxicology Letters 172S:S1-S240.

16 Becalski A, Lau BPY, Lewis D, Seaman SW. 2003. Acrylamide in foods: occurrence,

17 sources and modeling, Journal of Agricultural and Food Chemistry 51:802-808.

18 Boon PE, De Mul A, van der Voet H, van Donkersgoed G, Brette M, van Klaveren JD.

19 2005. Calculations of dietary exposure to acrylamide, Mutation Research 580:143-

$20 \quad 155$.

21 CIAA. 2007. Confederation of the Food and Drink Industries in the EU. The CIAA

22 acrylamide "toolbox". Rev. 11, December 2007.

23 http://www.ciaa.be/documents/brochures/toolbox\%20rev11\%20nov\%202007final.p

$24 \quad \underline{\mathrm{df}}$ 
1 De Wilde T, De Meulenaer B, Mestdagh F, Govaert Y, Vandeburie S, Ooghe W,

2 Fraselle S, Demeulemeester K, Van Peteghem C, Calus A, Degroodt JM, Verhé R.

3 2005. Influence of storage practices on acrylamide formation during potato frying,

$4 \quad$ Journal of Agricultural and Food Chemistry 53:6550-6557.

5 Dybing E, Sanner T. 2003. Risk assessment of acrylamide in foods. Toxicological $6 \quad$ Sciences $72: 144$.

7 Dybing E, Farmer PB, Andersen M, Fennell TR, Lalljie SPD, Muller DJG, Olin S, 8 Peterson BJ, Schlatter J, Scholz G, Scimeca JA, Slimani N, Törnqvist M, Tuijtelaars

9 S, Verger P. 2005. Human exposure and internal dose assessments of acrylamide in 10 food. Food and Chemical Toxicology 43:365-410.

11 EC. 2000. Risk Assessment of acrylamide (CAS No. 79-06-1, EINECS No. 201-173-7).

12 Draft Risk Assessment Report Prepared by the UK K.Svensson et al. / Food and 13 Chemical Toxicology 41 (2003) 1581-1586 1585 on Behalf of the European Union 14 in the Framework of Council Regulation (EEC) 793/93 on the Evaluation and 15 Control of the Risks of "Existing" Substances. European Commission, Joint 16 Research Centre, European Chemicals Bureau, Ispra, October 2000. Available: 17 http://ecb.jrc.it/existing-chemicals/.

18 EC. 2007. Commission Recommendation of 3 of May 2007 on the monitoring of 19 acrylamide levels in food.

20 EFSA. 2005. European Food Safety Authority (EFSA). Opinion of the Scientific 21 Committee on a request from EFSA related to a harmonised approach for risk 22 assessment of substances which are both genotoxic and carcinogenic (Request No. 23 EFSA-Q-2004-020). Adopted on 18 October 2005 
1 Erdogdu SB., Palazoglu TK., Gökmen V., Senyuva HZ., Ekiz HI. 2007. Reduction of

2 acrylamide formation in French fries by microwave pre-cooking of potato strips.

3 Journal of the Science of Food and Agriculture, 87, 133-137

4 FAO/WHO. 2005. Joint FAO/WHO Expert Committee on Food Additives: Summary

5 and conclusions report from sixty-fourth meeting, Rome, 8-17 February 2005.

6 Available at ftp://ftp.fao.org/es/esn/jecfa/jecfa64_summary.pdf

7 FDA. 2004. Exploratory data on acrylamide in Food 2003. Total diet study results.

8 http://www.cfsan.fda.gov/ dms/acrydat2.html\#table4

9 FDA. 2006. The 2006 exposure assessment for acrylamide. M. DeNovi, May 2006.

10 available online at http://www.cfsan.fda.gov/ dms/acryexpo.html

11 Franke K, Sel M, Reimerdes EH. 2005. Quality related minimization of acrylamide

12 formation - An integrated approach. In Chemistry and Safety of Acrylamide in

13 Food. M. Friedman \& D. Mottram, Eds.: 357-369. Springer. New York, NY.

14 Friedman M. 2003. Chemistry, biochemistry, and safety of acrylamide. A review.

15 Journal of Agricultural and Food Chemistry 51:4504-4526

16 BVL. 2006. German Federal Office of Consumer Protection and Food Safety

17 (http://www.bvl.bund.de/cln_027/nn_521172/EN/01_Food/04_Acrylamid_en/05

18 Signalwerte_en/signalwerte_node.html_nnn=true) (accessed on 2007).

19 Gertz C, Klostermann S. 2002. Analysis of acrylamide and mechanisms of its formation

20 in deep-fried products. European Journal of Lipid Science and Technology 104:

$21 \quad 762-771$.

22 Gökmen V., Senyuva HZ. 2007 Acrylamide formation is prevented by divalent cations

23 during the Maillard reaction. Food Chemsitry, 103, 196-203.

24 Granda C, Moreira RG, Tichy SE. 2004. Reduction of acrylamide formation in potato

25 chips by low-temperature vacuum frying. Journal of Food Science 69:E405-E411. 
1 IARC. 1994. International Agency for Research on Cancer. Monographs on the

2 Evaluation of Carcinogenic Risks to Humans: Some Industrial Chemicals No. 60.

3 IARC, Lyon, France

4 IRMM. 2006. Institute for Reference Materials and Measurements: Acrylamide 5 Monitoring Database. Available online:

\section{$6 \quad$ http://www.irmm.jrc.be/html/activities/acrylamide/database.htm}

7 Kita A, Brathen E, Knutsen SH, Wicklund T. 2004. Effective ways of decreasing 8 acrylamide content in potato crisps during processing. Journal of Agricultural and $9 \quad$ Food Chemistry 52:7011-7016.

10 Konings EJ, Baars AJ, van Klaveren JD, Spanjer MC, Rensen PM, Hiemstra M, van 11 Kooij JA, Peters PW. 2003. Acrylamide exposure from foods of the Dutch 12 population and an assessment of the consequent risks. Food and Chemical 13 Toxicology 41:1569-1579.

14 MAPA. 2007. La alimentación en España, Ed. Ministerio de Agricultura, Pesca y 15 Alimentación, Madrid.

16 Matthäus B, Haase NU, Vosmann K. 2004. Factors affecting the concentration of 17 acrylamide during deep-fat frying of potatoes. European Journal of Lipid Science 18 Technology 106:793-801.

19 Matthys C, Bilau M, Govaert Y, Moons E, De Henauw S, Willems JL. 2005, Risk 20 assessment of dietary acrylamide intake in Flemish adolescents. Food and Chemical $21 \quad$ Toxicology 43:271-278.

22 Mestdagh F, Maertens J, Cucu T, Delporte K, Van Peteghem C, De Meulenaer B. 2008. 23 Impact of additives to lower the formation of acrylamide in a potato model system 24 through $\mathrm{pH}$ reduction and other mechanisms. Food Chemistry 107:26-31. 
1 Morales FJ, Arribas-Lorenzo G. 2008. The formation of potentially harmful compounds

2 in churros, a Spanish fried-dough pastry, as influenced by deep drying conditions.

$3 \quad$ Food Chemistry 109:421-425.

4 Morales FJ, Capuano E, Fogliano V. 2008. Mitigation Strategies to Reduce Acrylamide

5 Formation in Fried Potato Products. Annals of the New York Academy of Sciences

$6 \quad 1126: 89-100$.

7 Mosbach-Schulz O, Seiffert I, Sommerfeld C. 2003. Abschätzung der Acrylamid-

8 Aufnahme durch hochbelastete Nahrungsmittel in Deutschland, Internet 2003.

9 http://www.bfr.bund.de/cms/media.php/70/abschaetzung_der_acrylamid_aufnahme

$10 \_$durch_hochbelastete_nahrungsmittel_in_deutschland_studie.pdf

11 Noti A, Biedermann-Brem S, Biedermann M, Grob K, Albisser P, Realini P. 2003.

12 Storage of potatoes at low temperature should be avoided to prevent increased

13 acrylamide during frying or roasting. Mitteilungen aus Lebensmitteluntersuchung

14 und Hygiene 94:167-180.

15 Parzelfall W. 2008. Minireview on the toxicity of dietary acrylamide. Food and 16 Chemical Toxicology 46:1360-1364.

17 Pedreschi F, Leon J, Mery D, Moyano P, Kaack K, Granby K. 2007. Colour 18 development and acrylamide content of pre-dried potato chips. Journal of Food $19 \quad$ Engineering 79:786-793.

20 Pedreschi F, Kaack K, Granby K. 2004. Reduction of acrylamide formation in potato 21 slices during frying. LWT - Food Science and Technology 37:679-685.

22 Pedreschi F, Kaack K, Granby K. 2006. Acrylamide content and colour development in 23 fried potato strips. Food Research International 39:40-46. 
1 Petersen BJ, Tran N. 2005. Exposure to acrylamide. Placing exposure in context. In

2 "Chemistry and Safety of acrylamide in Food". Ed. M. Friedman \& D. Mottram, 3 Springer Science, NY.

4 Roach JAG, Andrzejewski D, Gay ML, Nortrup D, Musser SM. 2003. Rugged 5 LCMS/MS survey analysis of acrylamide in foods, Journal of Agricultural and Food $6 \quad$ Chemistry 51:7457-7554.

7 Rosén J, Hellenäs KE. 2002. Analysis of acrylamide in cooked foods by liquid 8 chromatography tandem mass spectrometry. The Analyst 127:880-882.

9 Rufian-Henares JA, Morales FJ. 2006. Determination of acrylamide in potato chips by a 10 reversed-phase LC-MS method based on a stable isotope dilution assay. Food 11 Chemistry 97:555-562.

12 Rufian-Henares JA, Arribas-Lorenzo G, Morales FJ. 2007. Acrylamide content in 13 selected Spanish foods: Survey of biscuits and bread derivatives. Food Additives 14 and Contaminants 24:343-350.

15 Senyuva HZ, Gökmen V. 2006 Interference-free determination of acrylamide in potato 16 and cereal-based foods by a laboratory validated liquid chromatography-mass 17 spectrometry method. Food Chemistry 97:539-545.

18 Shipp A, Lawrence G, Gentry R, McDonald T, Bartow H, Bounds J, Macdonald N,

19 Clewell H, Allen B, Van Landingham C. 2006. Acrylamide: review of toxicity data 20 and dose-response analyses for cancer and noncancer effects. Critical Reviews in 21 Toxicology 36:481-608.

22 Svensson K, Abramsson L, Becker W, Glynn A, Hellenäs KE, Lind Y, Rosén J. 2003. 23 Dietary intake of acrylamide in Sweden. Food and Chemical Toxicology 41:15811586. 
1 Taeymans D, Wood J, Ashby P, Blank I, Studer A, Stadler RH, Gonde P, Van Eijck P,

2 Lalljie S, Lingnert H. 2004. A review of acrylamide: an industry perspective on

3 research, analysis, formation, and control. Critical Reviews in Food Science and

$4 \quad$ Nutrition 44:323-347.

5 Tareke E, Rydberg P, Karlsson P, Eriksson S, Törnqvist M. 2002. Analysis of 6 acrylamide, a carcinogen formed in heated foodstuffs. Journal of Agricultural and $7 \quad$ Food Chemistry 50:4998-5006.

8 Wenzl T, de la Calle MB, Anklam E. 2003. Analytical methods for the determination of 9 acrylamide in food products: a review. Food Additives and Contaminants 20:88510902.

11 Wenzl T., Anklan E. 2007. European Union database of acrylamide levels in food. 12 Update and critical review of the collection. Food Additives and Contaminants, 24, $13 \quad 5-12$.

14 WHO/JECFA (2005) $64^{\text {th }}$ meeting, Roa $7-17^{\text {th }} \quad$ February.

15 http://www.who.int/ipcs/food/jecfa/summaries/en/summary_report_64_final.pdf

16 Wilson KM, Rimm EB, Thompson KM, Mucci LA 2006. Dietary acrylamide and 17 cancer risk in humans: a review. Journal für Verbraucherschutz und 18 Lebensmittelsicherheit 1:19-27.

19 Zhang Y, Zhang GY, Zhang Y. 2005. Occurrence and analytical methods of acrylamide 20 in heat-treated foods-review and recent developments. Journal of Chromatography 21 A 1075:1-21. 


\section{$1 \quad$ Figures Captions.}

2

3 Figure 1. Box-and-Whisker plot (a) and distribution graph for acrylamide content in

4 Spanish potato crisps. Empty bar represent samples declared as low fat content $(<25 \%)$

5 by industrials. Dotted lines represent media and observed signal value.

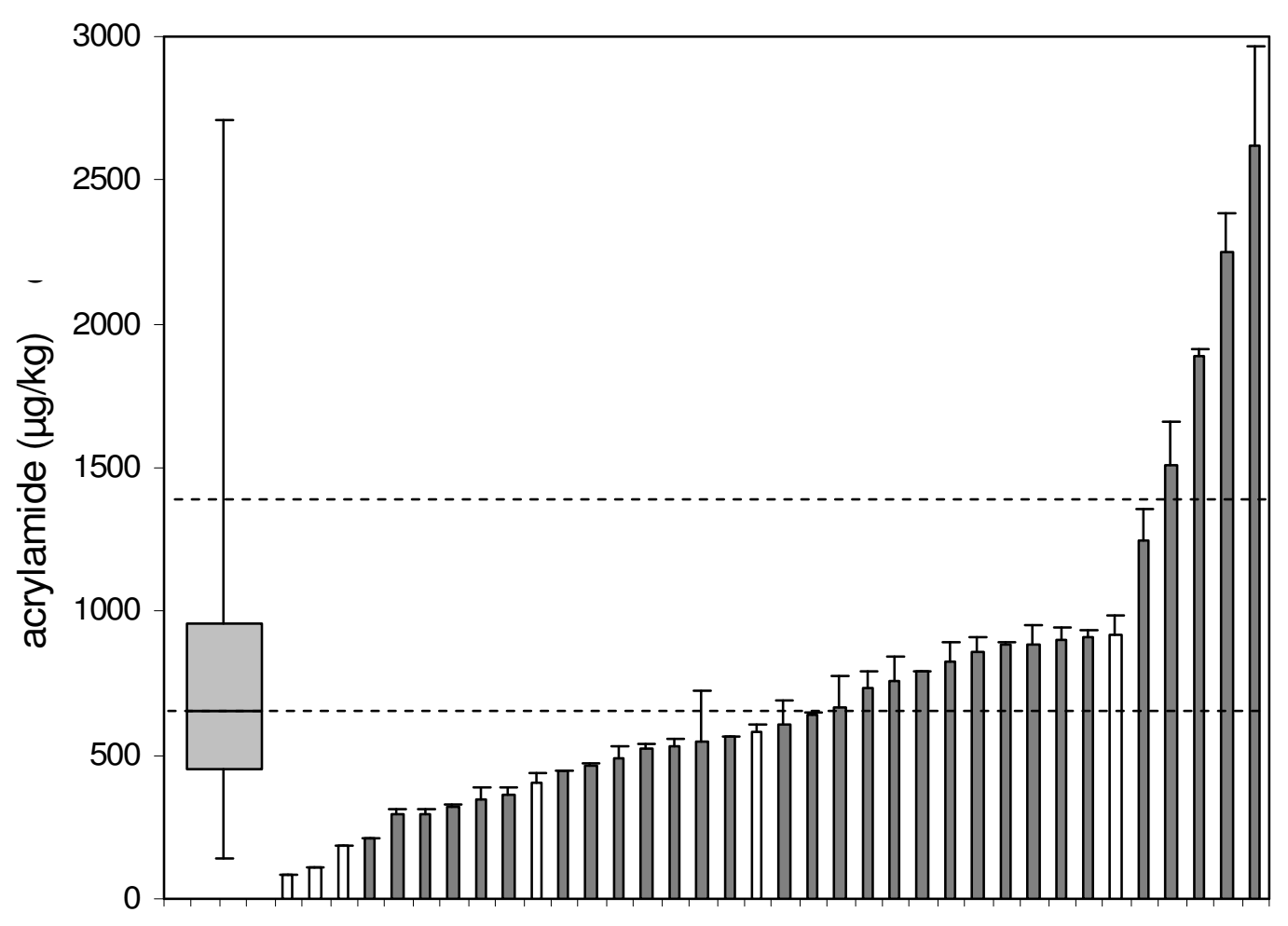


2 Figure 2. Smooth density plot for levels of acrylamide in the 2008 potato crisps

3 sampling and 2004 sampling (Rufian-Henares and Morales, 2005; dotted line).

4

5

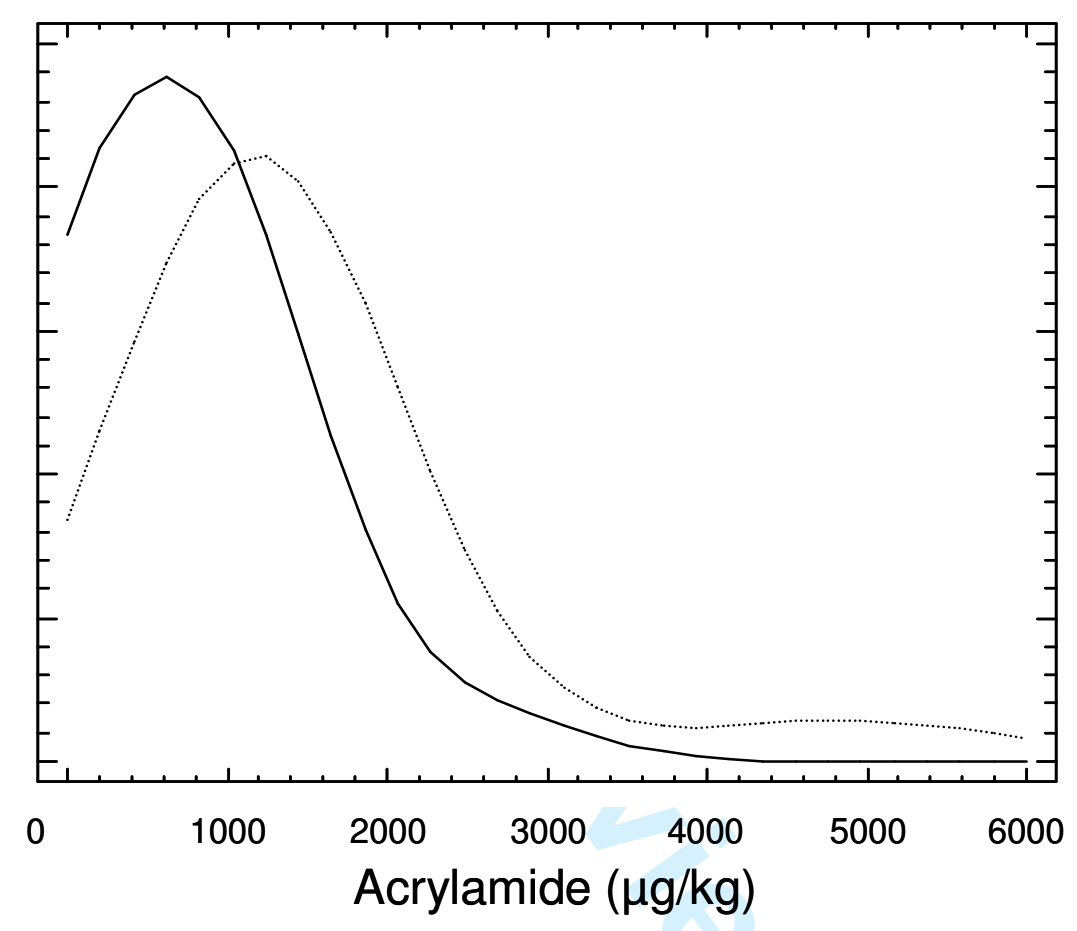

6 


\section{TABLES}

Table I. Contribution of potato crisps to dietary acrylamide exposure in different studies. Sum of potato crisps, French fries and roasted potatoes contribution (*).

\begin{tabular}{|c|c|c|c|c|c|}
\hline Country & Reference & $\begin{array}{c}\text { Total } \\
\text { intake } \\
\mu \mathrm{g} / \mathrm{kgbw} / \mathrm{day}\end{array}$ & $\begin{array}{c}\text { Potato } \\
\text { crisps } \\
\%\end{array}$ & $\begin{array}{c}\text { partial } \\
\text { contribution } \\
\mu \mathrm{g} / \mathrm{kgbw} / \mathrm{day}\end{array}$ & $\begin{array}{l}\text { Age } \\
\text { Year }\end{array}$ \\
\hline USA & FDA (2006) & 0,440 & 11 & 0,045 & $>2$ \\
\hline Sweeden & Svensson et al. (2003) & 0,500 & 9 & 0,045 & $18-74$ \\
\hline The Netherlands & Konings et al. (2003) & 0,480 & 31 & 0,149 & $1-97$ \\
\hline The Netherlands & Konings et al. (2003) & 1,040 & 31 & 0,322 & $7-18$ \\
\hline The Netherlands & Boon et al. (2005) & 0.5 & 15 & 0.075 & $1-97$ \\
\hline The Netherlands & Boon et al. (2005) & 1.1 & 18 & 0.198 & $1-6$ \\
\hline Norway & Dybing \& Sanner (2003) & 0,490 & 18 & 0,086 & $16-79$ ఠ \\
\hline Norway & Dybing \& Sanner (2003) & 0,460 & 17 & 0,080 & $6-79 q$ \\
\hline Norway & Dybing \& Sanner (2003) & 0,530 & 40 & 0,212 & $10-30 \AA$ \\
\hline Germany & Mosbach-Schulz et al. (2003) & 0,987 & $38 *$ & $0,371^{*}$ & $7-14$ \\
\hline Germany & Mosbach-Schulz et al. (2003) & 0,573 & $29 *$ & $0,166^{*}$ & $19-64$ \\
\hline Belgium & Matthys et al. (2005) & 0,513 & 12 & 0,062 & $13-18$ \\
\hline Brazil & Arisseto et al. (2007) & 0,550 & $60 *$ & $0,330^{*}$ & $11-17$ \\
\hline France & $\operatorname{AFSSA}(2005)$ & 1,400 & $26^{*}$ & $0,357 *$ & $3-8$ \\
\hline France & AFSSA (2005) & 0,500 & $32 *$ & $0,161^{*}$ & $9-14$ \\
\hline France & AFSSA (2005) & 0,500 & 24 & 0,122 & $>15$ \\
\hline Spain & Morales (2004, unpublished) & 0,409 & 22 & 0,090 & total \\
\hline
\end{tabular}


1 Table II. Contribution of potato crisps to the dietary exposure to acrylamide ( $\mu \mathrm{g} / \mathrm{kg} \cdot \mathrm{bw} / \mathrm{day})$ for the total Spanish population according to 2 different categories based on household consumption. Total National included household + Institutions + Restaurants consumption.

\begin{tabular}{|c|c|l|c|}
\hline Category & & \multicolumn{1}{|c|}{ Class } & AA exposure \\
\hline Total National & & & 0.042 \\
\hline Household National & Level & & 0.035 \\
\hline \multirow{2}{*}{ Autonomous Community } & Min & Canary Islands & 0.023 \\
& Max & Catalonia & 0.046 \\
\hline \multirow{2}{*}{ Population size } & Min & $<2000$ inhabitants & 0.026 \\
& Max & $>500000$ inhabitants & 0.041 \\
\hline \multirow{2}{*}{ Socioeconomic status } & Min & Low & 0.023 \\
& Max & High+medium-high & 0.046 \\
\hline \multirow{2}{*}{ Family members } & Min & 5 or more subjects & 0.026 \\
& Max & 1 subject & 0.055 \\
\hline \multirow{2}{*}{ Cycle of life } & Min & Couples with kids $(<7$ years) \& & 0.029 \\
& & Couples with sons $(>17$ years $)$ & 0.064 \\
\hline
\end{tabular}


1 Table III. Exposure (based on 3-day records) to acrylamide for children (body weight

$234.48 \mathrm{~kg}, \mathrm{n}=903$ ) and adult (body weight $68.48 \mathrm{~kg}, \mathrm{n}=1060$ ) Spanish population. Data

3 expressed as $\mu \mathrm{gAA} / \mathrm{kg} \cdot \mathrm{bw} / \mathrm{day}$. Risk consumers are estimated at percentile 97.50. Mean,

4 min, max and $\mathrm{P}(90)$ refers to mean, minimum, maximum and percentile 95 of

5 acrylamide distribution in commercial potato crisps.

6

7

8

\begin{tabular}{ccccc} 
Children (7-12 years) & mean & $\min$ & $\max$ & $\mathrm{P}(95)$ \\
\hline Average consumer $=$ & 0.142 & 0.016 & 0.502 & 0.379 \\
Regular consumer $=$ & 0.428 & 0.047 & 1.516 & 1.145 \\
Risk consumer $=$ & 1.064 & 0.116 & 3.769 & 2.848
\end{tabular}

\begin{tabular}{ccccc} 
Adults $(>17-60$ years $)$ & Mean & Min & Max & P(95) \\
\hline Average consumer $=$ & 0.053 & 0.006 & 0.189 & 0.143 \\
Regular consumer $=$ & 0.250 & 0.027 & 0.887 & 0.670 \\
Risk consumer $=$ & 0.602 & 0.066 & 2.131 & 1.610
\end{tabular}

9 